\section{Clipping the Wings of Degree Mills in Nigeria \\ Peter Okebukola}

Peter Okebukola is Chairman of Council, Crawford University, Nigeria, and immediate-past Executive Secretary, National Universities Commission. Email:pokebukola@yahoo.com.

$\mathrm{T}$ he Nigerian higher education system, with 297 institutions (universities, polytechnics, and colleges of education) and enrolling over 3.5 million students, is the most expansive in Africa. Highly respected in the past, the system is now sadly paled among other quality-depressing factors by activities of degree mills. Persons who want certificates at any cost and lack the basic entry requirements for admission into available spaces in approved institutions make up one of the pools from which degree mills draw their students. The other source is the candidates leftover after an admission season. In 2008, it is expected that about 80 percent of the over one million candidates who sat for the Universities Matriculation Examination will fall into this category. Holders of degrees from these bogus institutions are decried by employers in the private and public sector for their poor knowledge and skills in the fields they claim to have tertiary-level education. Attainment of the Nigerian vision of being one of the top 20 economies by 2020 will be compromised by the injection of such poor-quality graduates into the economy. Herein lies the distaste for and the raison d'etre for government's clampdown on degree mills.

Four major institutional arrangements qualify as degree mills in the Nigerian context. These establishments constitute unapproved satellite campuses of local and foreign universities, unapproved subdegree institutions serving as affiliates of approved universities, unapproved programs run in universities, and online courses offered by rogue foreign providers. From I995 to 200I, these "pollutants" produced annually about I5 percent of total university "graduates" in Nigeria. Between 200I and 2004, a sharp drop in output occurred, followed by a slight rise between 2005 and 2006 . By 2007, the activities of the National Universities Commission (NUC), the regulatory agency for the universities, induced a significant drop in the number of institutions and their enrollment. Sustenance of the momentum of the NUC clampdown is expected to reduce the activities of degree mills to nonsignificance.

\section{IMPOSING RESTRICTIONS}

In the past 9 years, a flurry of activity has been directed at eradicating the degree mills — seven of which are noteworthy. First, by I999, a national policy was enacted by the National Council on Education. This highest policymaking body directed the closure of all local and foreign satellite campuses. Policy enactment turned out to be a good initiative in ridding the higher education terrain of degree mills.

The second strategy is enforcement and application of sanctions. Not until 200I did NUC enact enforcement of the policy on closure. In a dramatic national raid, NUC, backed up by the force of the antiriot wing of the police under orders of the inspector-general, took steps to close the illegal campuses. The success rate was about 90 percent since some campuses that initially terminated operations reemerged clandestinely to run their programs. Between 2002 and 2005, the number and vigor of the degree mills declined perceptibly.

The third action is the establishment and enforcement of the carrying capacity of approved programs - the maximum number of students that available resources can support in the production of quality graduates. This regulation ensured that universities do not overenroll through illegal degree-mill operations. As sanctions, overenrolled programs are decertified by NUC.

Four major institutional arrangements qualify as degree mills in the Nigerian context.

Fourth, NUC is partnered with the Department of State Services-Nigeria's secret service-in locating, arresting, and prosecuting operators of unapproved universities and satellite campuses. The fifth strategy is public disclosure in national electronic and print media of the names of illegal tertiary institutions placed in the national media by the executive secretary of NUC. Potential students, parents, and employers have started to shun these institutions. With dwindling clientele, such institutions are expected to fade into oblivion.

Since 2007, as a major stride against degree mills, NUC has directed all approved universities to make full disclosure of their programs. The commission followed up with resource verification leading to granting of formal approval where minimum academic standards for setting up programs are met. These programs will be listed in the Directory of Approved Programmes in the Nigerian University System. Since online and cross-border programs are yet to be backed up for recognition purposes by any national policy or law, the publication of the directory, as a seventh strategy, will screen out degree mills from institutions at which potential students would desire enrollment.

\section{Are We Winning the War?}

On May 5, 2008, NUC announced the closure of Io illegal universities. This thinned the ranks of the degree mills and signaled others in the ignoble league that NUC was close at their heels. In addition, the May 2008 mop-up accreditation of pro- 
grams was another edge to the NUC sword for eliminating degree mills.

In the last three years, the National Youth Service Corps Scheme into which university graduates are fed has stepped up its regime of screening out products from bogus institutions and unapproved programs. Together, these efforts have translated into an estimated 70 percent success rate in the war against degree mills.

\section{CONCLUSION}

Degree mills thrive on fertile grounds provided by a combination of desperate students and easy-profit-seeking providers. While efforts are under way in Nigeria to make the terrain as difficult as possible for the duo, we cannot guarantee that Nigeria will become a degree-mill-free zone in the shortest possible time. The increasing number of candidates who fail to secure university admission and who want to obtain university degrees at all costs makes such an assurance unrealistic. Hope, however, rests on the conviction that NUC will sustain its clampdown on degree mills, indeed, with increasing vigor.

\section{Globalization,}

\section{Internationalization, and}

\section{Rankings}

\section{Ellen Hazelkorn}

Ellen Hazelkorn is professor, Director of Research and Enterprise and Dean of the Graduate Research School, Dublin Institute of Technology. She is also Director of the Higher Education Policy Research Unit, Dublin Institute of Technology, Dublin, Ireland. E-mail: ellen.hazelkorn@dit.ie.

$\mathrm{W}$ thin days of each other, Times Higher Education published two articles (July 3, 2008 and July IO, 2008) and the Chronicle of Higher Education (July II, 2008) published one about how domestic demographic shifts across Organization for Economic Cooperation and Development (OECD) countries could cause a near doomsday scenario for, in this case, UK and Japanese higher education. UK universities were urged to "buckle up for a rough ride," while the latter paper told tales of how Japanese universities were responding to escalating competition by "sending recruiters out to high schools, holding open houses for prospective students, building swimming pools and revamping libraries, and recruiting more foreign students." Stories of what the Daily Yomiuri calls the "scramble for students" or the Economist calls the "battle for brainpower" are increasingly common as higher education moves center stage in the geopolitical contest for an increasing share of the global economic market. Indeed, the battle for talent now complements more traditional struggles for natural resources. Government policy aims to offset domestic demographic shifts with internationalization-once seen as a policy of cultural exchange. Global competition is reflected in the rising significance and popularity of rankings that attempt to measure the talent-catching capacity of higher education institutions.

The following observations are based on an international

Countries with high levels of international students benefit from the contribution they make to domestic research and development, while those with low numbers find it "more difficult . . . to capitalize on this external contribution to domestic human capital production."

survey of higher education leaders in 2006 and interviews at higher education institutions in Australia, Japan, and Germany during 2008.

\section{Higher Education Internationalization Policy}

Internationalization has become both a university and a government priority - not just because it is seen as a sign of global competitiveness but also because it serves as a way to ensure the capacity to participate in world science. According to the OECD, countries with high levels of international students benefit from the contribution they make to domestic research and development, while those with low numbers find it "more difficult . . . to capitalize on this external contribution to domestic human capital production."

Previously protected by geography from the full effect of competition, Japan's 726 universities now face considerable pressure. According to census statistics, the number of I8year-old Japanese has fallen to I.3 million in 2007 from 2.05 million in I992. The figure is likely to drop to I.2I million by 2009. According to the International Herald Tribune (June 2I, 2007), nearly a third of the nation's four-year universities were unable to fill all of their openings, and others have now closed. The government has set a target of increasing the number of international students from the current 100,000 , to 300,000 by 2020 .

Germany faces similar demographic challenges, with the greatest impact expected after 20I5. The federal government predicts that even with 200,000 immigrants a year, Germany's population will shrink from today's 82.5, to 75 million by 2050 . International student recruitment is now seen as vital as the number of students entering higher education and then matriculating from undergraduate to postgraduate falls. The government had anticipated restricting matriculation to only 